\title{
Stratigraphy and depositional setting of the lower Missourian (Pennsylvanian) Bethany Falls and Mound Valley limestones, analogues for age-equivalent ooid-grainstone reservoirs, Kansas
}

\author{
John A. French ${ }^{1}$ and W. Lynn Watney ${ }^{1}$
}

\begin{abstract}
Significant quantities of mobile oil remain in Pennsylvanian reservoirs in the midcontinent region of the United States. To recover this oil efficiently, we must understand the factors that control heterogeneity in these complex reservoirs. One way to accomplish this is to evaluate reservoir-quality carbonate units that occur in both the outcrop and the shallow subsurface as analogues to equivalent producing zones. In southeastern Kansas the lower Missourian Bethany Falls and Mound Valley limestones contain oolitic grainstones similar to coeval productive lithofacies that occur in the deeper subsurface to the west. Depositional sequence analysis of these grainstonebearing units suggests that (1) at least two cycles of relative sea-level change led to the deposition of discrete oolitic grainstones that are separated by subaerial exposure surfaces, with these surfaces strongly influencing the vertical distribution of porosity, and (2) the character and distribution of reservoir-scale grainstone buildups were strongly controlled by preexisting depositional topography.
\end{abstract}

Pennsylvanian rocks of the midcontinent region of the United States ultimately may produce 9 billion barrels of oil (Rascoe and Adler, 1983). In Kansas 500 million barrels of unswept mobile oil remain in existing Pennsylvanian reservoirs (BPO/ Toris database). Most of these reservoirs occur in relatively thin and discontinuous oolitic and bioclastic grainstones, phylloid-algal, chaetetid, and crinoid-bryozoan-dominated carbonate buildups, and quartz-rich sandstones (Watney et al., 1989). The occurrence of individual carbonate reservoirs is related to both favorable depositional settings, such as high-energy shoals, and pervasive early diagenesis associated with subaerial exposure, where porosity commonly developed through dissolution of carbonate grains by meteoric waters.

Porosity and permeability development in these Pennsylvanian carbonate reservoirs is commonly heterogeneous because of the complex interplay among depositional, diagenetic, and tectonic processes that influenced reservoir evolution, and both vertical and lateral heterogeneity can be significant. For example, the 80-well Cahoj field in Rawlins County, Kansas, is compartmentalized into producing zones that vary from 1 to 10 wells (Watney et al., 1992). These compartments are apparently discontinuous pods of skeletal grainstone that were variably affected by carbonate cementation or dissolution (Watney, 1980). Porosity is only an indirect indication of potential producibility in this reservoir; high porosities are not necessarily associated with high

1. Kansas Geological Survey and Department of Geology, University of Kansas, Lawrence, KS 66047.

Current Research on Kansas Geology, Summer 1993, Bulletin 235, Kansas Geological Survey, Lawrence, pp. 27-39. permeabilities. In another case the $\mathrm{K}$ zone in the Victory field has high porosity but limited areas of high permeability (Watney and French, 1988). The Victory field example parallels the situation observed in the rocks that are the focus of this article. Such reservoir heterogeneities must be understood by development geologists to maximize recovery from these fields through application of secondary and tertiary recovery methods.

To better understand the vagaries of porosity and permeability trends in carbonate reservoirs in the lower Missourian Lansing and Kansas City Groups in Kansas, analogues of producing zones are being developed through studies of ageequivalent rocks in outcrops and shallow cores and by using an extensive wire-line log database. The reservoirs generally occur at depths of several thousands of feet in central and western Kansas, and lithologic information of the quality provided by outcrops and closely spaced cores is typically lacking. Thus analogue studies will provide a detailed understanding of the controls on reservoir geometry and quality in strata equivalent to producing zones.

Our purposes here are to describe and interpret the occurrence of porous carbonate lithofacies in the Bethany Falls and Mound Valley limestones that crop out or are near the surface in Bourbon and Allen counties, southeastern Kansas. These units are lithologically similar and genetically equivalent to the oil- and gas-producing $\mathrm{K}$ zone that occurs in the subsurface in central and western Kansas (Watney, 1984; Watney and French, 1988). Information about processes such as relative sea-level change and diagenesis, which profoundly affect the distribution of porous and permeable lithofacies in this unit, is potentially transferable to the equivalent producing zones. 


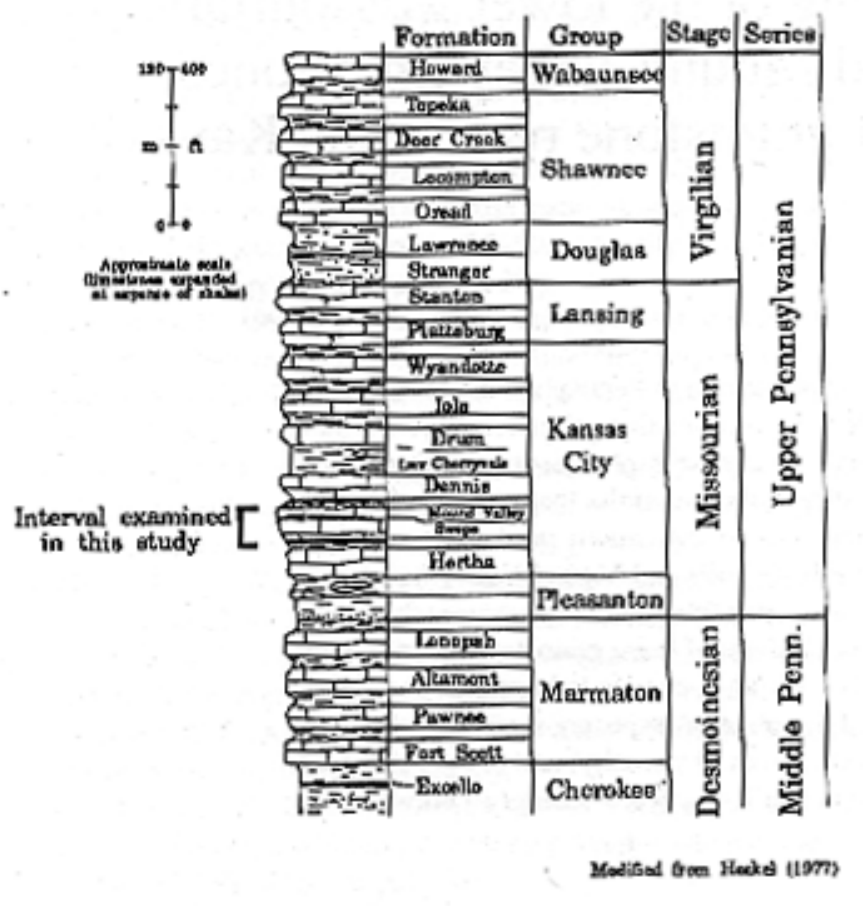

Figure 1. Schematic section of a portion of the Pennsylvanian System in Kansas showing the interval discussed in this article.

\section{Stratigraphic interval and area of study}

The stratigraphic interval under study includes the lower Missourian Swope and Mound Valley limestones (fig. 1). The total area considered here is an approximately $2,400-\mathrm{mi}^{2}$ $\left(6,200-\mathrm{km}^{2}\right)$ area of southeastern Kansas that includes the lower Missourian outcrop belt and adjacent areas to the west where the units occur in the shallow subsurface at depths of less than $300 \mathrm{ft}(91 \mathrm{~m})$ (fig. 2). A smaller 200-mi ${ }^{2}\left(520-\mathrm{km}^{2}\right)$ area (fig. 2) is discussed in detail.

\section{Stratigraphic cyclicity in the lower Missourian}

Laterally continuous cyclic strata typify the Pennsylvanian System in many areas of the world and are especially well developed in the midcontinent of North America [e.g., Weller (1930), Moore (1931), and Heckel (1977, 1984)]. Missourian cyclothems of Kansas typically consist of (in ascending order) a thin transgressive limestone or siliciclastic-limestone couplet, a nonsandy phosphatic black shale, a relatively thick regressive limestone, and a generally mud-dominated siliciclastic unit of variable thickness that may contain coals, sandstones, or red beds (Heckel, 1984) (fig. 3). Blocky mudstones and seat earths, interpreted as paleosols that formed during periods of prolonged subaerial exposure, commonly occur just above the regressive limestone or within the overlying

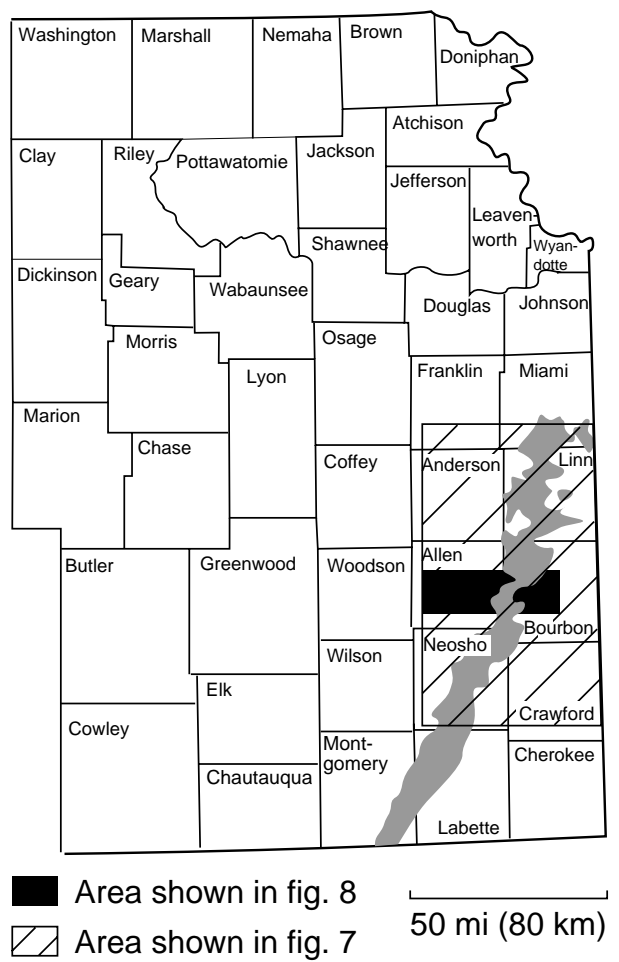

Figure 2. Partial map of Kansas showing locations of detailed maps of study area.

siliciclastic unit. The upper portions of many regressive limestones also show evidence of subaerial exposure in the form of penetrative laminated crusts or microkarstic features. Individual lower Missourian cyclothems typically range from less than $20 \mathrm{ft}$ (about $6 \mathrm{~m}$ ) thick to over $80 \mathrm{ft}$ (about $25 \mathrm{~m}$ ) thick, with some variation within individual cyclothems related to factors such as shelf position, siliciclastic content, and the presence of local carbonate buildups.

Mechanisms of cyclothem deposition have been vigorously debated since cyclicity in Pennsylvanian strata was first described by Udden (1912). Key features of cyclothems that bear on their origin include (1) the great lateral persistence of individual cyclothems and some of their component members, such as the black shales; some units can be correlated from westernmost Missouri to southeastern Colorado, a distance of more than $400 \mathrm{mi}$ (almost $650 \mathrm{~km}$ ); (2) the presence of lithofacies, such as the phosphatic black shales, that may represent water depths of the order of $650 \mathrm{ft}$ (200 m) (Heckel, 1977), and of paleosols, which formed during subaerial exposure; and (3) estimates of cycle periods that are of the order of 120-400 k.y. for major cycles [see Heckel (1990, p. 44)]. These factors, coupled with evidence that major continental glaciations occurred during the Upper Pennsylvanian (Crowell, 1978; Veevers and Powell, 1987), strongly suggest that Missourian cyclothems investigated in this 


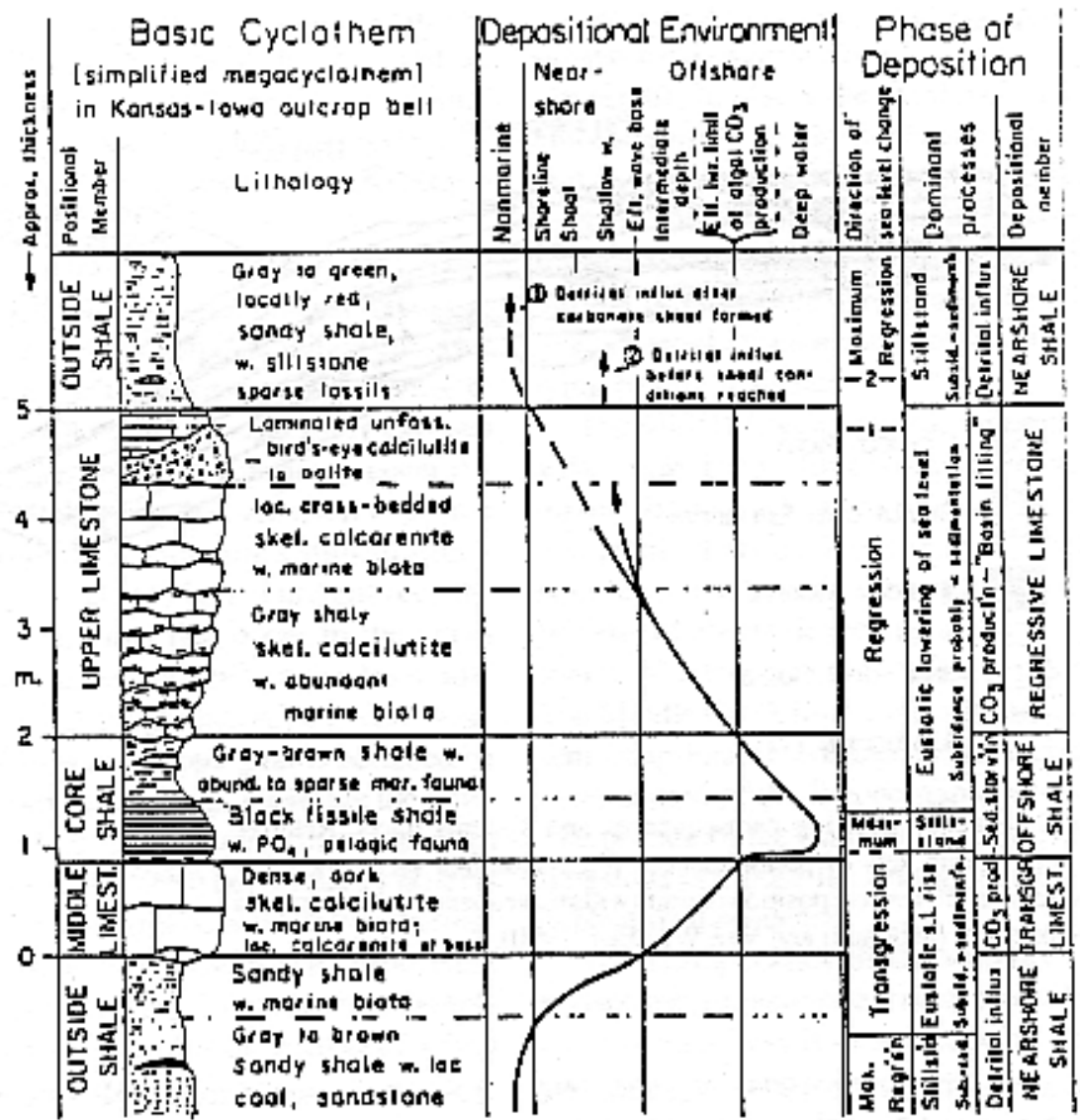

\section{Generd Model for Limils of Carbonate Deposition on Sloping Shelf}

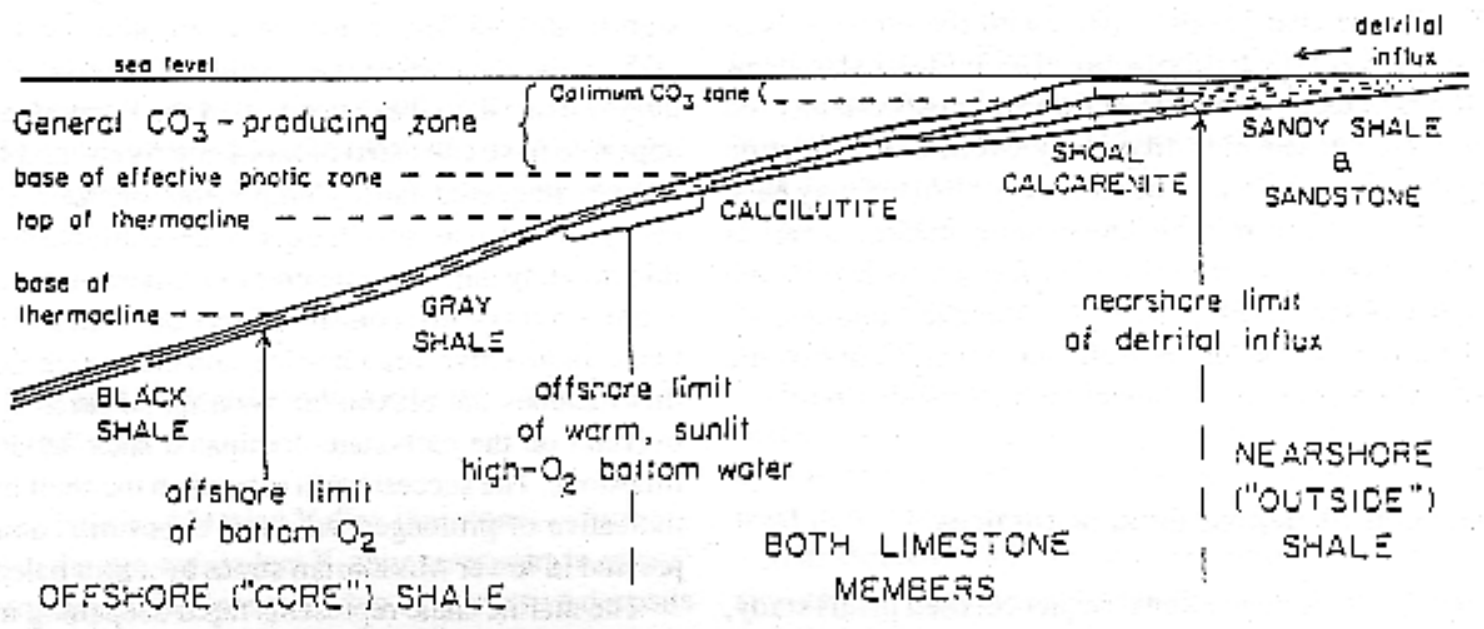

Figure 3. Generalized model of deposition of midcontinent cyclothems; modified from Heckel $(1977,1984)$. 


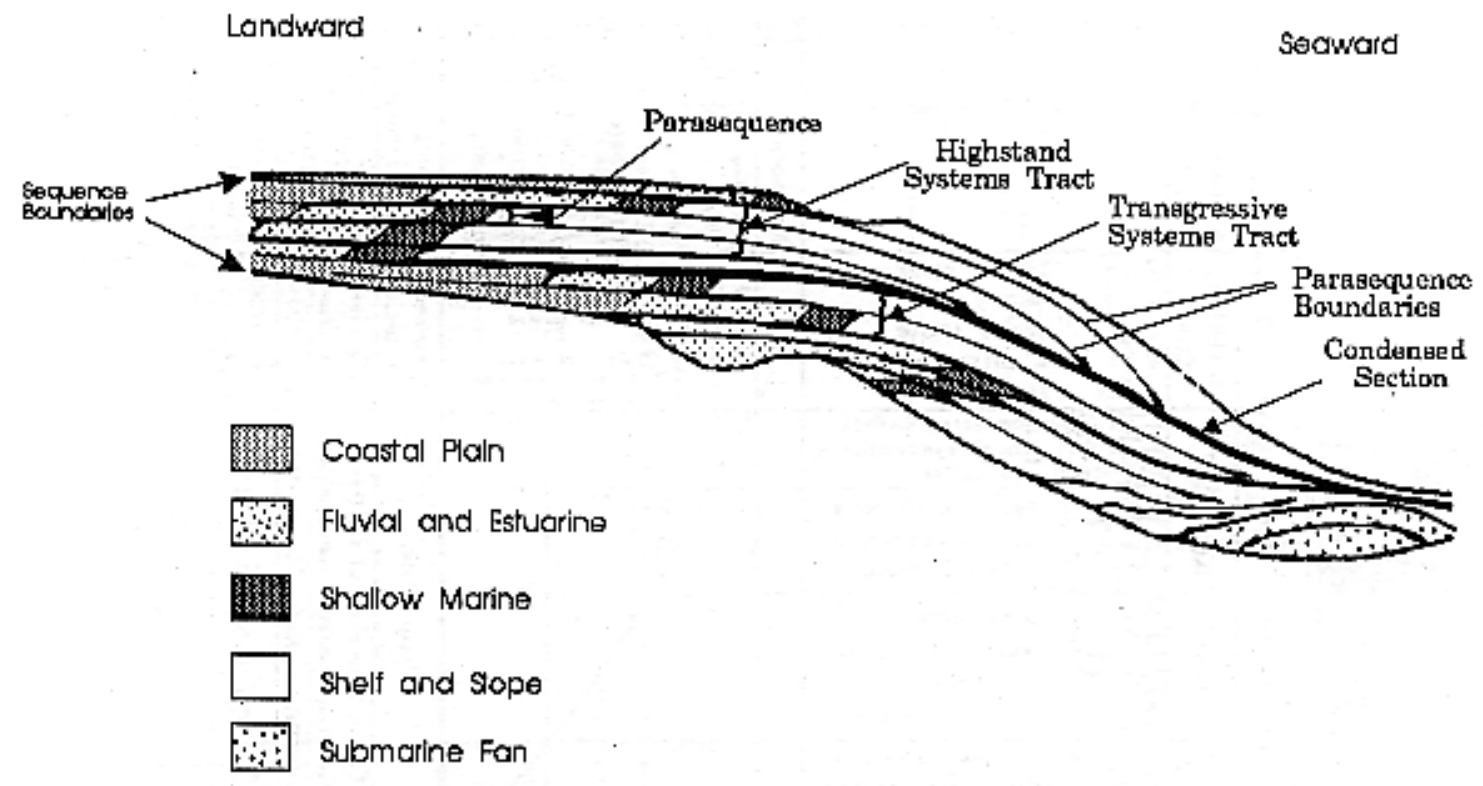

Figure 4. Depositional sequence showing parasequences and systems tracts. Relative position of facies belts within sets of parasequences (e.g., shoreline facies stepping landward or basinward) and the vertical position of units within a sequence are key criteria used to define systems tracts (Mitchum and Van Wagoner, 1990).

study are the product of glacial-eustatic sea-level fluctuations with amplitudes possibly in the range of $200-650 \mathrm{ft}$ (60-200 m).

The climate changes associated with these episodes of glaciation likely affected the nature of individual cyclothems also. Rates of tectonic movement were almost certainly too low to have caused high-frequency cyclic sedimentation during the Pennsylvanian [see Heckel (1990)] but may have been important controls on longerterm thickness trends and facies patterns. More localized processes, such as stream avulsion and the development of carbonate buildups, affected individual cycles as well but did not control the overall nature of cyclic sedimentation (Heckel, 1990).

\section{Cyclothems as depositional sequences}

The concept of the depositional sequence, used in this study, has become important in stratigraphic analysis in the last 15 years. A depositional sequence is defined as a relatively conformable succession of genetically related strata bounded by unconformities or their correlative conformities (Mitchum et al., 1977) (fig. 4). Many midcontinent cyclothems were delineated on the basis of disconformities, including subaerial exposure surfaces, making them among the first defined genetic-stratigraphic sequences. Therefore these cyclothems are excellent candidates for sequence-stratigraphic analysis, in which individual depo- sitional sequences are defined and analyzed in terms of a major cycle of rise and fall of relative sea level. However, the character of a depositional sequence in the Pennsylvanian strata is significantly different from rocks of other ages.

The major cycles of rise and fall of relative sea level that largely controlled the deposition of the Pennsylvanian strata appear to have consisted of rapid, relatively simple rises and slower, staggered falls. Components of the cycles can be easily related to those of the cyclic depositional sequences. A thin flooding unit (the transgressive limestone) is overlain by a thin $[<5 \mathrm{ft}(<2 \mathrm{~m})]$ condensed section, which is generally a black, radioactive, organic-rich, and metal-rich marine shale that includes the maximum flooding surface. The shale is overlain on the carbonate-dominated shelf by a regressive limestone. The succession is capped on the shelf by a surface indicative of prolonged subaerial exposure, commonly expressed in lower Missourian strata by a thin paleosol.

The marine shale represents rapid deepening into marine highstand conditions. This shale is widespread, with individual units being correlatable by means of both biostratigraphic methods (Boardman and Heckel, 1989) and wire-line logs. The lack of benthic fauna and the organic-rich nature of this facies suggest long-term stability of anoxic settings suited to the preservation of organic matter; one example would be the base of a deep, restricted water mass. Accordingly, water depths during black shale deposition were probably considerably greater than the overall thickness of the 
individual cycle, such that the potential accommodation space was in excess of the thickness of the sediment column. Direct evidence in this area from an underlying cycle suggests that the relative sea-level change was at least $150 \mathrm{ft}$ (46 m) (Watney et al., 1989).

The upper (regressive) limestone exhibits an overall shallowing-upward trend; in some locations there is evidence of minor relative sea-level rises and falls (including episodes of subaerial exposure) during the course of shallowing to final long-term subaerial exposure. The subaerially exposed surface and associated diagenetic overprinting generally occur on subtidal strata, suggesting that subaerial exposure resulted from sea-level fall rather than from sediment aggradation [see Goldhammer et al. (1991)]. Furthermore, the relatively small-scale stratal units that occur in the upper limestones are not parasequences reflecting episodes of marine flooding and subsequent progradation [see Van Wagoner et al. (1990)] but basinward-stepping units bounded by surfaces indicative of abrupt shallowing. Therefore the limestone does not represent a highstand systems-tract deposit in the sense of Van Wagoner et al. (1990) but primarily reflects falling stages of sea level and should be considered a fallingsea-level or forced-regressive (Posamentier et al., 1990; Hunt and Tucker, 1992) systems-tract deposit. Finally, the paleosols that cap the limestone are widespread on the shelf and are best developed landward (presumably representing more time) (Watney, 1980). Locally, the overprinting associated with early meteoric diagenesis during subaerial exposure is substantial (Goldstein et al., 1991; Watney, 1980).

Fourth-order-scale cycles (0.1-1 m.y.) such as these Missourian depositional sequences are in some cases defined as parasequences in other stratal successions. The widespread subaerial exposure surfaces that bound these cyclothems define these units as depositional sequences [see Mitchum et al. (1977)]. Depositional sequences are scale independent (Mitchum et al., 1977, p. 56).

\section{Description and depositional sequence analysis of the study interval}

The Bethany Falls and Mound Valley limestones, which are analogous to the age-equivalent K-zone reservoirs in central and western Kansas, are interpreted to be regressive deposits within two separate depositional sequences, herein termed the Swope and Mound Valley sequences (fig. 5). In the study area the Swope sequence ranges in thickness from $31 \mathrm{ft}$ to 44 $\mathrm{ft}(9.5-13.4 \mathrm{~m})$ and in ascending order consists of the Elm Branch shale and Middle Creek limestone member, the Hushpuckney Shale Member, the Bethany Falls Limestone Member, and the Ladore Shale.

The marine portion of the Elm Branch shale overlies a subaerial exposure surface that occurs at the top of the Hertha Limestone. In places the basal part of the Elm Branch is an unfossiliferous, blocky mudstone with some coaly interbeds that is interpreted to be largely a paleosol. Overlying the inferred paleosol is a gray to dark-gray shale that contains scattered marine fossils, such as brachiopods. This portion of the unit is interpreted to represent the initial marine flooding of a subaerial exposure surface that developed on the underlying Hertha sequence.

The Middle Creek limestone member consists mainly of a dark gray-brown lime wackestone that contains abundant marine fossils, such as brachiopods, bryozoans, foraminifers, and phylloid algae. There is little evidence of either early marine or freshwater cementation in this unit, probably because of abrupt deepening and little opportunity for infiltration of meteoric waters after deposition (Heckel, 1983). The Middle Creek limestone member is interpreted to represent open-marine conditions, reflecting post-Elm Branch continuation of the Swope transgression. Together the marine portion of the Elm Branch shale and the Middle Creek limestone compose the transgressive portion of the Swope depositional sequence.

The Hushpuckney Shale Member consists of a core of phosphatic, organic-rich, radioactive black shale that largely lacks benthic fossils or evidence of infaunal activity. This core shale is sandwiched between gray burrowed marine mudstones and shales. The black shale facies represents condensed sedimentation and is interpreted to be the maximum flooding of the midcontinent shelf during "Swope time."

The Bethany Falls Limestone Member consists of two basic lithofacies. The lower part of the unit consists mainly of a nonporous bioclast wackestone with echinoderms, brachiopods, bryozoans, and phylloid algae constituting the bulk of the biota (fig. 6a). The upper portion is variably developed and consists of a generally porous, crossbedded ooid-bioclast grainstone and well-washed packstone (figs. 6b and 6c). The upper surface of the unit in southeastern Kansas commonly shows evidence of subaerial exposure, such as rhizoliths, dissolution features, and laminated crusts. In the study area this surface is overlain in at least two cores by a mudstone unit that is interpreted to be a paleosol, at least in its lower part.

The Bethany Falls Member is interpreted to be a regressive deposit that represents shallowing of marine conditions to subaerial exposure. This interpretation is based on the general upward transition from diversely fossiliferous wackestones to oolitic grainstones and packstones. This unit is considered a deposit of the forced-regressive systems tract within the Swope sequence, reflecting progressive shallowing and ultimately subaerial exposure as sediments accumulated during relative sea-level fall.

The Ladore Shale in the study area is a greenish unfossiliferous, blocky mudstone that exhibits such features as slickensides and root tubules. Such attributes suggest that the Ladore is a paleosol that marks the top of the Swope sequence. 


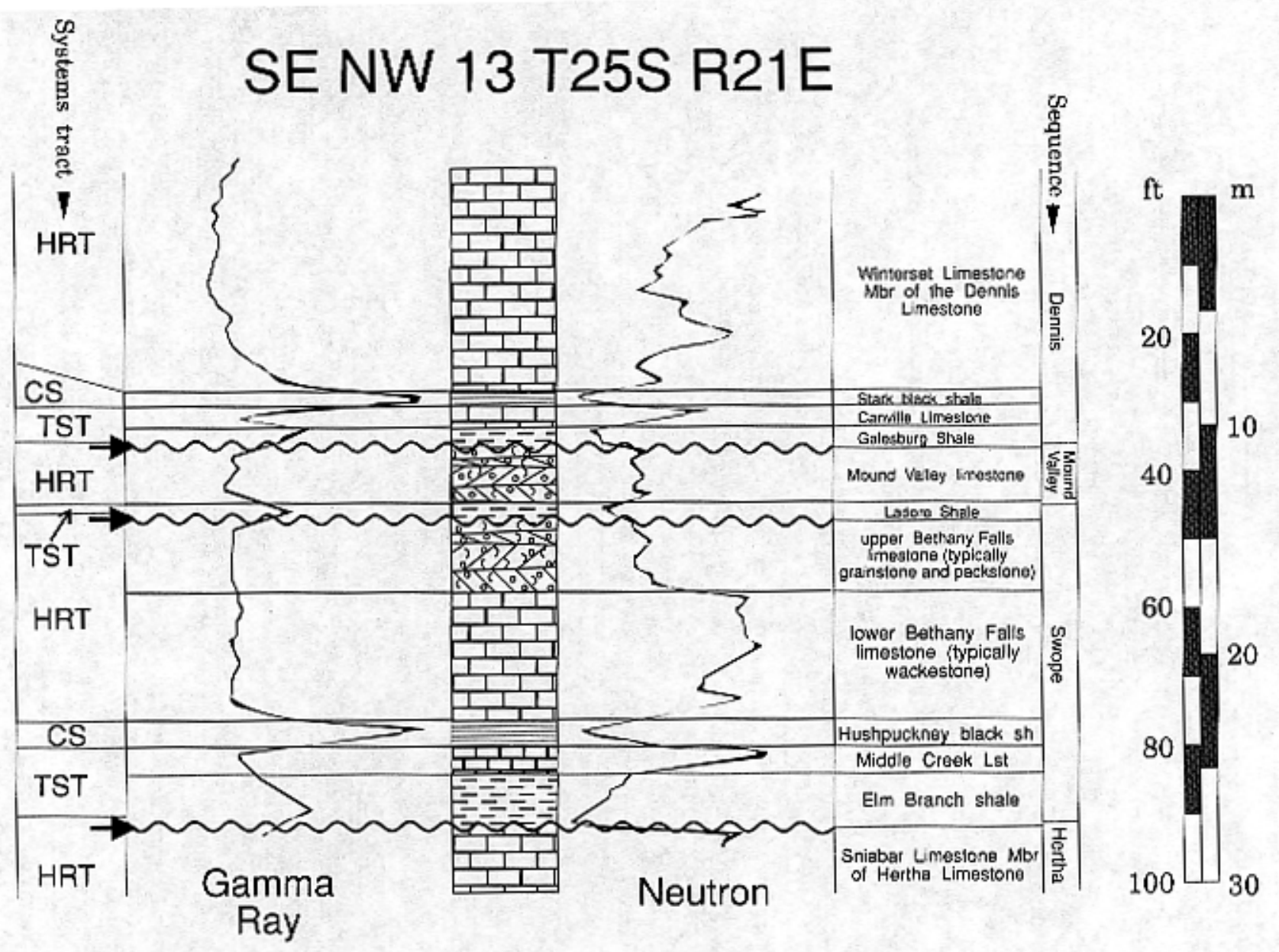

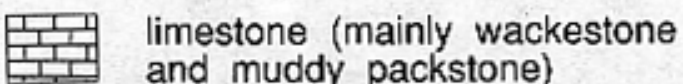

and muddy packstone)

limestone (mainly grainstone and well-washed packstone)

mudstone and shale (Includes paleosols)

phosphatic black shale

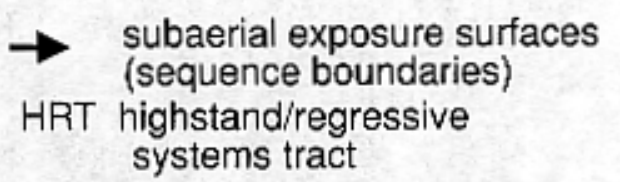

TST transgressive systems tract CS condensed section (core shale)

Figure 5. Representative gamma-ray-neutron log and stratigraphic column of study interval in west-central Bourbon County, Kansas. The grainstones and packstones of the Bethany Falls and Mound Valley limestones are the focus of this article. Inferred depositional sequences and systems tracts are also shown. 
The Mound Valley sequence is considerably thinner and less well developed than the Swope sequence. It ranges up to $10 \mathrm{ft}(3 \mathrm{~m})$ in thickness in the study area but is absent in many places. Regionally, the Mound Valley limestone thickens southward from the study area and is largely absent to the north. Therefore the sampling location is near the northward (i.e., updip) pinchout of the Mound Valley limestone, making its occurrence sporadic as a result of variations in local accommodation space, autogenic processes such as grainstone bar development, and probably erosion. The Mound Valley limestone directly overlies either the Ladore paleosol or the uppermost Swope carbonate unit. Where most completely developed, the Mound Valley sequence consists of three basic lithofacies types (in ascending order):

1. A basal relatively fine-grained, low-porosity peloidbioclast packstone;

2. An upper variably porous, bioclast-ooid grainstone and well-washed packstone (fig. 6d);

3. A gray-green unfossiliferous blocky mudstone that displays slickensides and root traces and in places contains calcareous lumps that resemble caliche nodules. This upper muddy unit is interpreted to be a paleosol. Lithostratigraphically, it is part of the overlying Galesburg Shale, a unit that above the paleosol is the transgressive systems tract of the overlying Dennis sequence. Where the Mound Valley limestone is absent, the lower Galesburg paleosol lies on the upper Bethany Falls Limestone Member; in such cases it is unclear whether or not the Ladore and Galesburg paleosols are amalgamated, because neither paleosol has distinctive attributes that are currently recognized.

Most of the Mound Valley is interpreted as a regressive unit and is either a late highstand or a forced-regressive systems-tract deposit. The lower peloidal portion may represent the transgressive deposits of the encroaching Mound Valley sea, because the relatively fine grain size and intensely micritized nature of the grains (suggesting slower accumulation) may reflect slightly greater water depths during deposition of that part of the sequence.

In a hierarchic sense the Mound Valley sequence represents a much smaller scale relative sea-level event than does the Swope sequence. Whereas the Mound Valley sequence is restricted to more basinal portions of the midcontinent basin, the Swope sequence can be traced onto and across the Central Kansas uplift and to the limit of the Missourian outcrop belt in Iowa (Heckel, 1986).

\section{Controls on the distribution of reservoir-type lithofacies}

In the study area both the Swope and the Mound Valley sequences contain porous oolitic zones in their upper parts (figs. 5 and 6b-d) that are similar to lithofacies that compose many of the hydrocarbon reservoirs that occur in the equivalent K zone in central and western Kansas (Watney, 1984). The distribution and possible origin of these reservoirlike lithofacies in the study area can be illustrated by a set of maps and cross sections (figs. 7-12).

The lowermost carbonate-dominated Missourian units (the Hertha Limestone, the Swope Limestone, including the Bethany Falls and Mound Valley limestones, and the Dennis Limestone) overlie the Pleasanton Formation (fig. 1), which consists mostly of homogeneous gray-green shale. The Pleasanton attains a thickness of over $180 \mathrm{ft}(55 \mathrm{~m})$ about $15-$ $25 \mathrm{mi}(24-40 \mathrm{~km})$ west of the outcrop belt and thins to less than $90 \mathrm{ft}(27 \mathrm{~m})$ along the outcrop of the Swope and Mound Valley sequences (figs. 7-9). This thinning is inferred to have resulted in a prominent depositional slope. Oolitic grainstones in the Swope and Mound Valley sequences tend to be thickest and best developed along this Pleasanton slope, presumably in response to higher energy conditions that prevailed there. The Pleasanton slope is interpreted as a major break in paleodepositional topography, which would have been conducive to the development of high-energy facies such as ooid shoals. In fact, detailed mapping has revealed five elongated west-northwest- to east-southeast-trending tracts of thick Bethany Falls limestone that correspond to accumulations of oolitic grainstones and packstones in the upper part of the unit. These areas of thick Bethany Falls limestone range from 1 to $3 \mathrm{mi}(1.6-4.8 \mathrm{~km})$ in width, and some are at least $10 \mathrm{mi}(16 \mathrm{~km})$ long (fig. 7). The oolitic lenses that trend normal to an underlying depositional slope resemble the tidally influenced oolitic sand bars that occur on the modern Great Bahama Bank (Ball, 1967). The individual modern sand belts are narrower, perhaps because of a coalescence of the ancient bars through time; alternatively, these apparently wide grainstone belts may reflect the lack of closely spaced control needed to resolve any smaller scale oolitic buildups that may be present.

Some of the best developed oolitic bars occur in association with a slight embayment in the Pleasanton slope (figs. 7 and 8). Such an embayment could have focused tidal currents, resulting in the observed grainstone bars. This embayment is also evident on isopach maps of the Nuyaka Creek to Hushpuckney interval and would be even more prominent on maps of the decompacted interval.

The best development of porous oolitic carbonate in the Swope sequence occurs in the central portion of individual bars, where these lithofacies are up to $14 \mathrm{ft}(4.3 \mathrm{~m})$ thick, and the total thickness of grainstone reaches almost $20 \mathrm{ft}(6 \mathrm{~m})$ (figs. 10-12). The porosity resulted from the early dissolution of ooids after an initial stage of cementation. The remaining interparticle space was generally filled later, with some porosity occluded with saddle dolomite that represents late-stage deeper burial conditions (Watney et al., 1993). Good high-permeability reservoir rocks are associated with molds that have become connected by crushing, fracturing, or dissolution of intervening cements. Porous oolite in the 

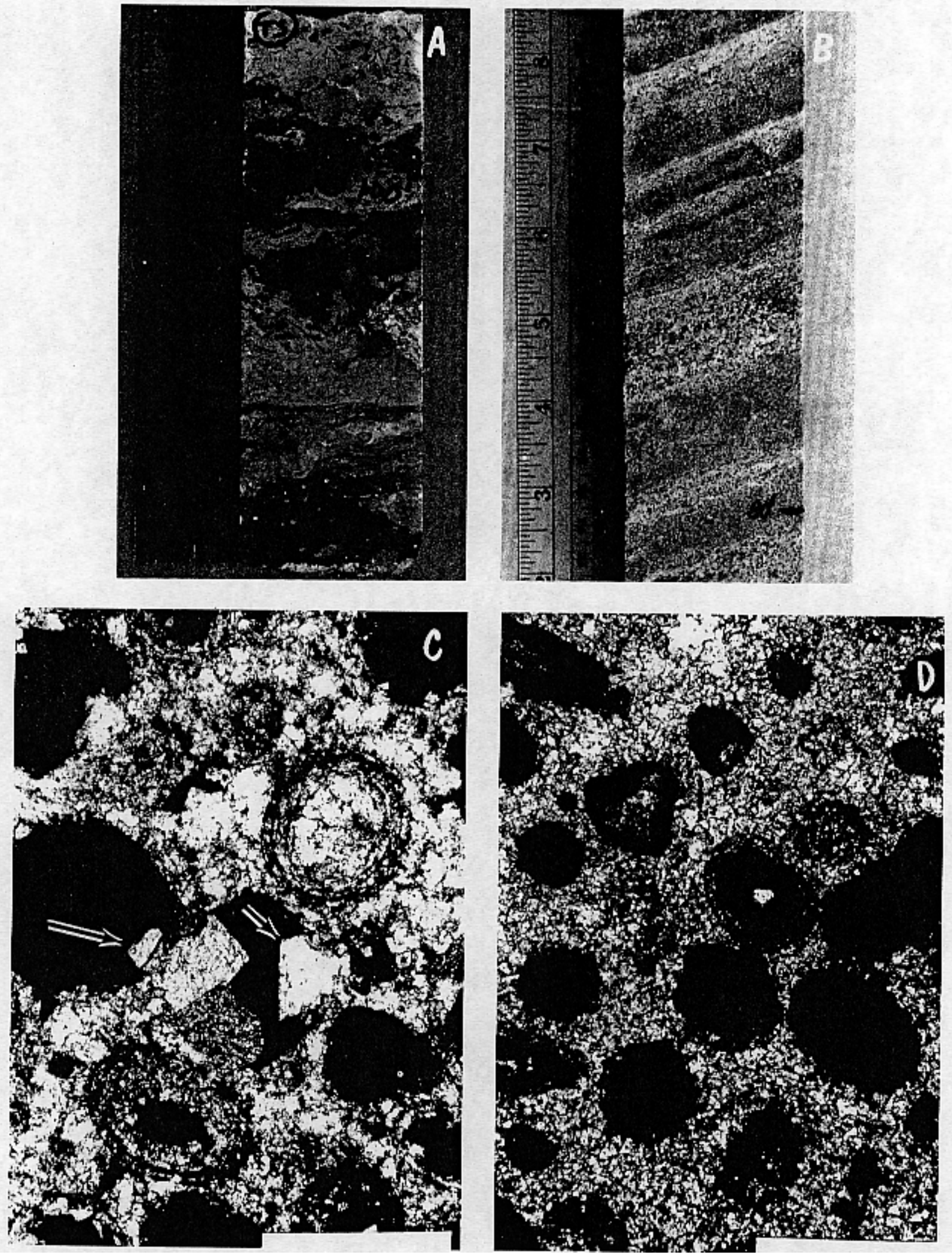

Figure 6 
Figure 6. (A) Argillaceous brachiopod-bryozoan-echinoderm whole-fossil wackestone typical of the lower Bethany Falls Limestone Member. The abundance of lime mud and a diverse and abundant biota suggest deposition in relatively deep normalmarine water. KGS Woodward no. 3, $99 \mathrm{ft}, 10 \mathrm{in}$., to $100 \mathrm{ft}, 4 \mathrm{in}$. (B) Crossbedded ooid-bioclast grainstone representative of the upper Bethany Falls Limestone Member in the study area. Crosssets over $3 \mathrm{ft}(1 \mathrm{~m})$ thick are common and contain beds and laminae of variable grain size and composition, sorting, and porosity development. KGS Woodward no. 3, $79 \mathrm{ft}, 6$ in., to 80 $\mathrm{ft}, 1$ in. (C) Oomoldic porosity (dark areas) within the upper Bethany Falls Limestone Member. Individual pores average $0.5-1 \mathrm{~mm}$ in diameter and are commonly partially to totally occluded by saddle dolomite (arrows). KGS Woodward no. 3, $73.4 \mathrm{ft}$. (D) Oomoldic and fossil moldic porosity in the Mound Valley limestone. Pores in this unit average $0.25-0.5 \mathrm{~mm}$ in diameter and have not been observed to have been affected by saddle dolomite precipitation. Bar $=1 \mathrm{~mm}$. KGS Woodward no. $3,64.5 \mathrm{ft}$.

Mound Valley sequence is up to $6 \mathrm{ft}(1.8 \mathrm{~m})$ thick and is thickest where it overlies one of the best developed bars in the Swope sequence (figs. 10-12). Interbar areas are essentially devoid of porous lithologies (figs. 10 and 11).

\section{Conclusions}

Carbonate grainstones similar to those that form important Missourian oil and gas reservoir facies are present in equivalent units at and near the outcrop belt in southeastern Kansas. Reservoir-type lithofacies are present in the highstand systems tracts of two distinct carbonate-dominated depositional sequences. At least two porous, oolitic zones, separated vertically and laterally by nonporous rocks, are present. Their deposition was controlled by fluctuations of relative sea level that were probably caused by glacial eustasy and therefore were worldwide in extent. In addition, the geometries of porous zones within each depositional sequence appear to have been influenced by preexisting topography. These relationships may provide clues for both exploration and production in the equivalent depositional sequences in the deeper subsurface.

Acknowledgments We thank Paul Enos and Robert Goldstein for their continuing help, both logistical and conceptual. This paper was prepared with the support of the U.S. Department of Energy under grant DE-FG22-90BC14434. However, any opinions, findings, conclusions, or recommendations expressed herein are those of the authors and do not necessarily reflect the views of the DOE. This paper was reviewed by Paul Enos, Jim Markello, Martin Gibling, and Bill Ross, and we thank them for their suggestions.

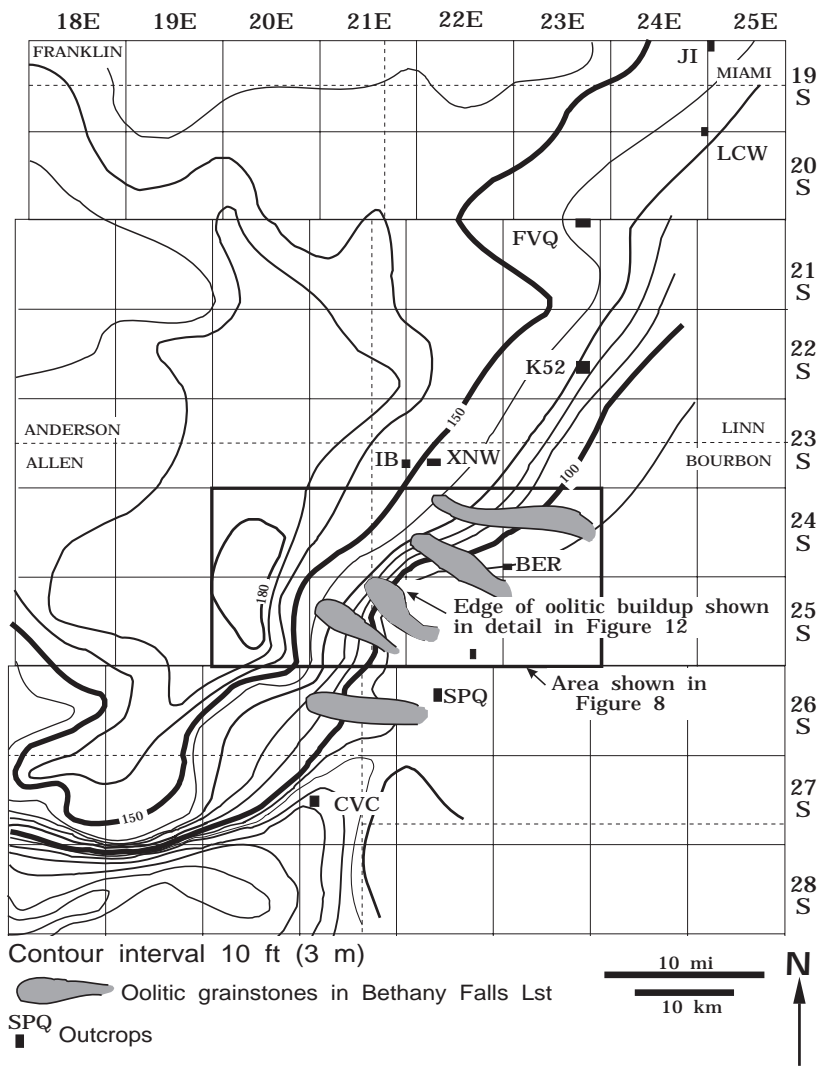

Figure 7. Isopach map of interval from base of Nuyaka Creek shale to top of Pleasanton Formation(two cycles below Bethany Falls Limestone Member). Stippled pattern shows areas of $>25$ $\mathrm{ft}(7.6 \mathrm{~m})$ Bethany Falls unit, which corresponds to ooliticgrainstone accumulations. Also shown is approximate location of detailed core transect at edge of one of the buildups (see fig. 12).

\section{References}

Ball, M. M., 1967, Carbonate sand bodies of Florida and the Bahamas: Journal of Sedimentary Petrology, v. 37, p. 556-591

Boardman, D. R., II, and Heckel, P. H., 1989, Glacial-eustatic sealevel curve for early Late Pennsylvanian sequence in northcentral Texas and biostratigraphic correlation with curve for midcontinent North America: Geology, v. 17, p. 802-805

Crowell, J. C., 1978, Gondwanan glaciation, cyclothems, continental positioning, and climate change: American Journal of Science, v. 278, p. 1,345-1,372

Galloway, W. E., and Brown, L. F., 1973, Depositional systems and shelf-slope correlations on cratonic basin margin, uppermost Pennsylvanian of north-central Texas: American Association of Petroleum Geologists Bulletin, v. 57, p. 1,185-1,218

Goldhammer, R. K., Oswald, E. J., and Dunn, P. A., 1991, Hierarchy of stratigraphic forcing-example from Middle Pennsylvanian shelf carbonates of the Paradox basin; in, Sedimentary modeling - computer simulations and methods for improved parameter definition, Franseen, E. K., Watney, W. L., Kendall, 


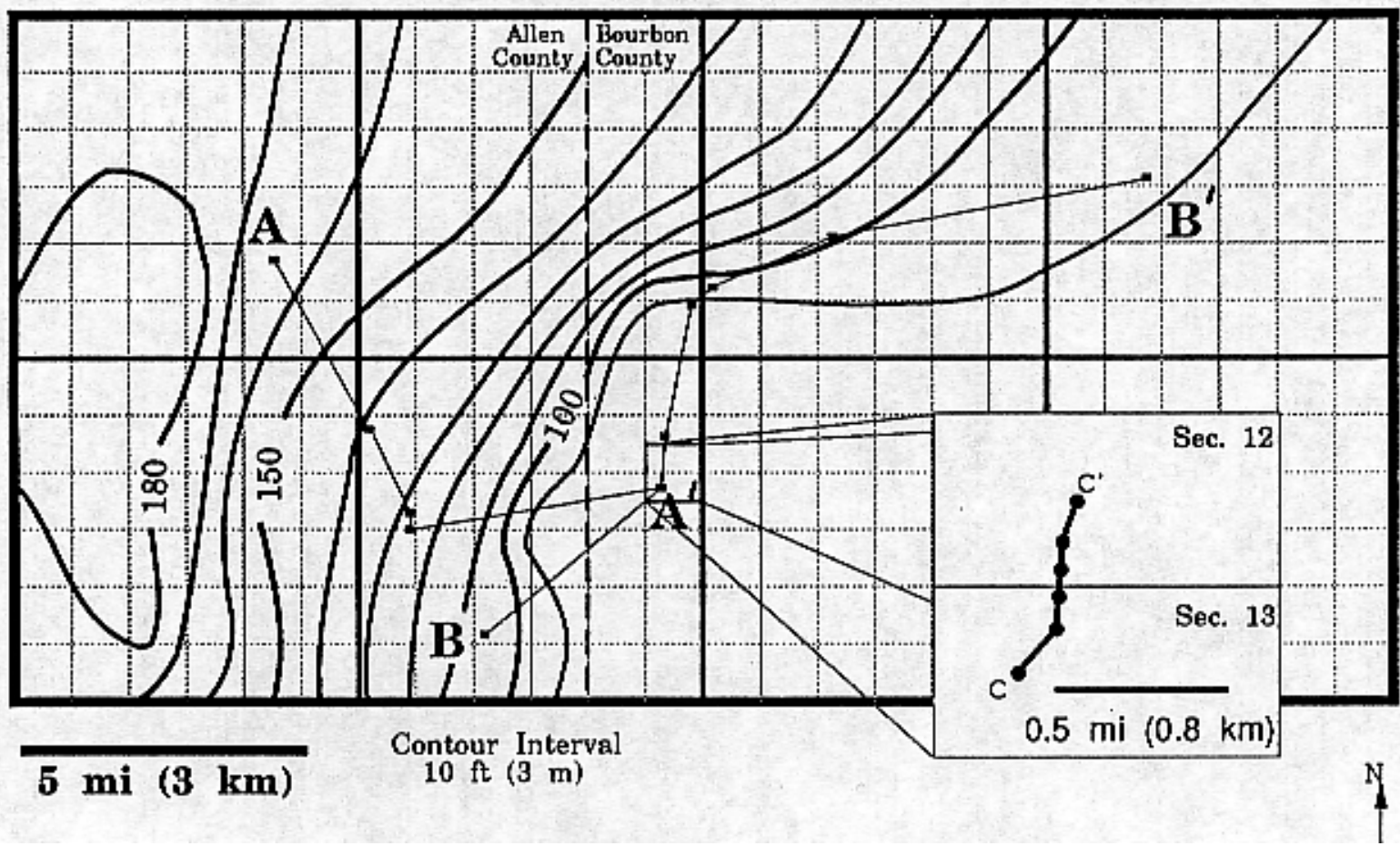

Figure 8. Detailed map of east-central Allen County and west-central Bourbon County, Kansas, showing thickness of interval from base of Nuyaka Creek shale to top of Pleasanton Formation. Cross-section locations are shown.

A

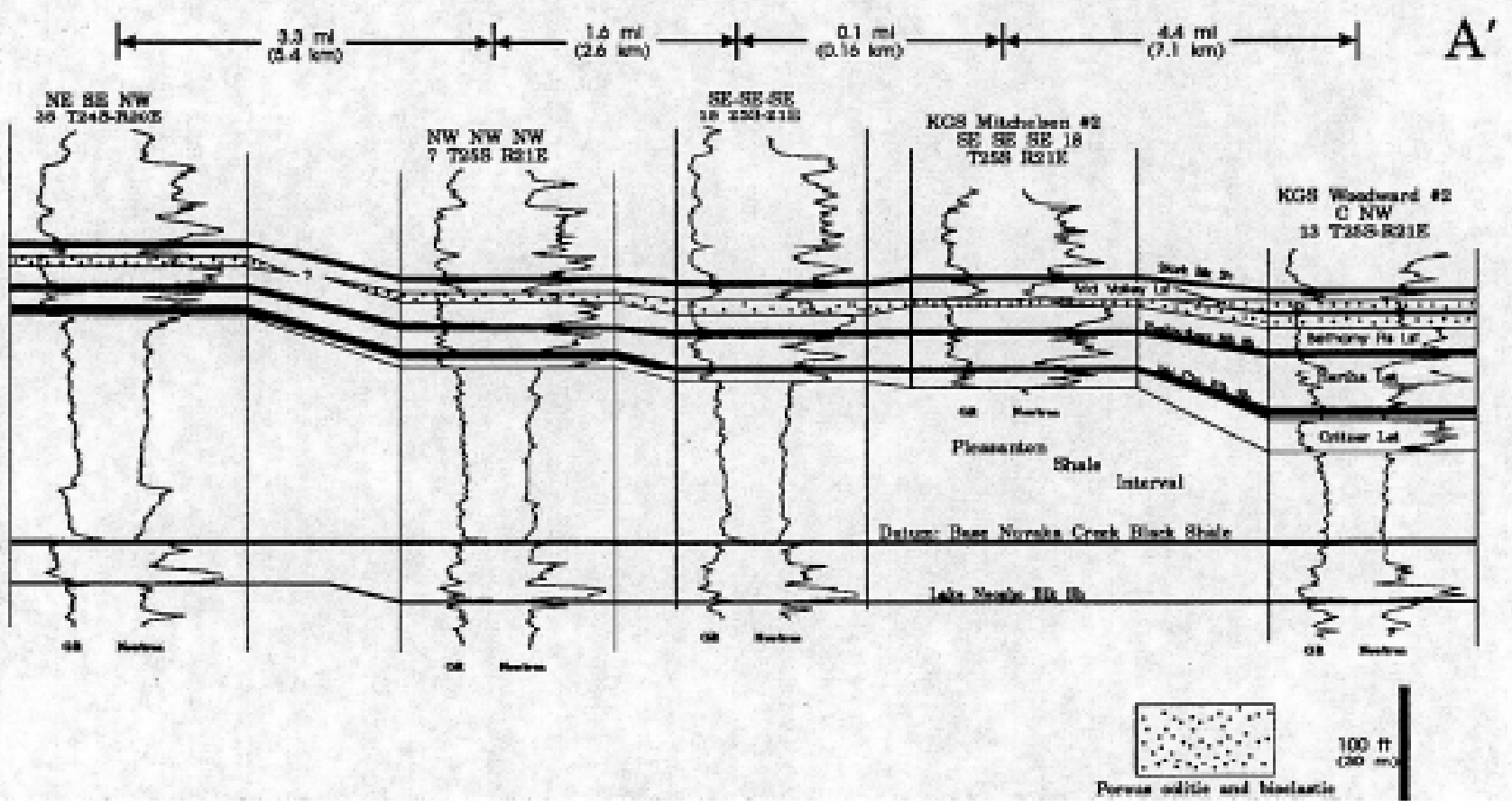

Figure 9. Northwest-southeast cross section showing thinning of Pleasanton Formation and occurrence of multiple Swope and Mound Valley oolitic lithofacies. Decompaction of the Pleasanton interval would accentuate vertical separation of oolites at west end of section (marked by “?”), making it more apparent that they are separate, perhaps being basinward-stepping parasequences. See fig. 8 for location of cross section. 


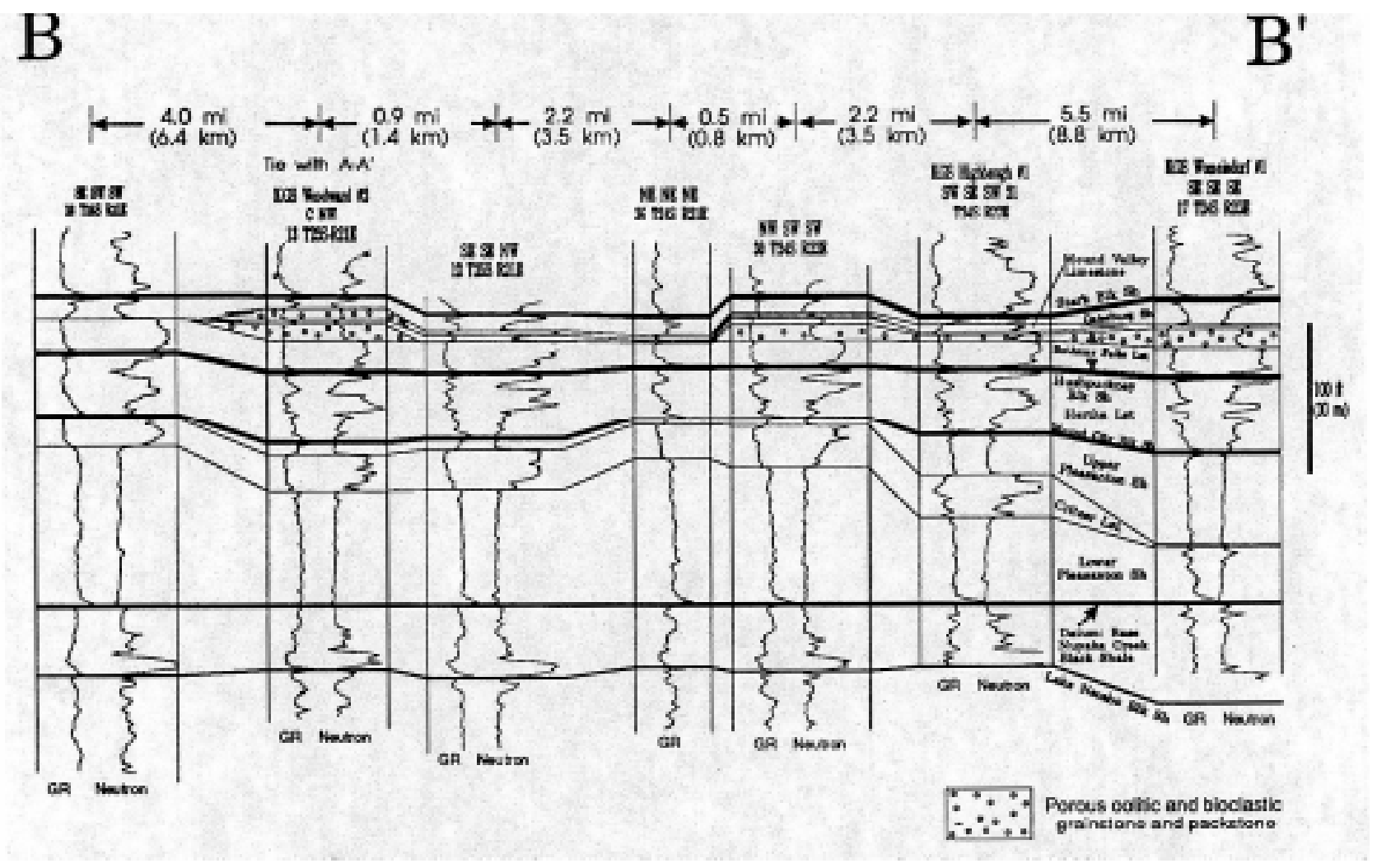

Figure 10. Southwest-northeast cross section roughly along strike of the Pleasanton siliciclastic wedge. This section shows two distinct oolitic buildups in the Bethany Falls and Mound Valley limestones. See fig. 8 for location of cross section.

C. G. St. C., and Ross, W., eds.: Kansas Geological Survey, Bulletin 233, p. 361-413

Goldstein, R. H., Anderson, J. E., and Bowman, M. W., 1991, Diagenetic responses to sea-level change-integration of field, stable isotope, paleosol, paleokarst, fluid inclusion, and cement stratigraphy research to determine history and magnitude of sealevel fluctuation; in, Sedimentary modeling — computer simulations and methods for improved parameter definition, Franseen, E. K., Watney, W. L., Kendall, C. G. St. C., and Ross, W., eds.: Kansas Geological Survey, Bulletin 233, p. 139-162

Heckel, P. H., 1977, Origin of phosphatic black shale facies in Pennsylvanian cyclothems of midcontinent North America: American Association of Petroleum Geologists, Bulletin, v. 61, p. $1,045-1,068$

, 1983, Diagenetic model for carbonate rocks in midcontinent Pennsylvanian eustatic cyclothems: Journal of Sedimentary Petrology, v. 53, p. 733-759

1984, Factors in midcontinent Pennsylvanian limestone deposition; in, Limestones of the midcontinent, Hyne, N. J., ed.: Tulsa Geological Society, Special Publication 2, p. 25-50 , 1986, Sea-level curve for Pennsylvanian eustatic marine transgressive-regressive depositional cycles along midcontinent outcrop belt, North America: Geology, v. 14, p. 330-334

, 1990, Evidence for global (glacial-eustatic) control over upperCarboniferous (Pennsylvanian) cyclothems in midcontinent
North America; in, Tectonic events responsible for Britain's oil and gas reserves, Hardman, R. F. P., and Brooks, J., eds.: Geological Society, Special Publication 55, p. 35-47

Hunt, D., and Tucker, M. E., 1992, Stranded parasequences and the forced regressive wedge systems tract - deposition during baselevel fall: Sedimentary Geology, v. 81, p. 1-9

Mitchum, R. M., Jr., and Van Wagoner, J. C., 1990, High-frequency sequences and their stacking patterns-sequence-stratigraphic evidence of high-frequency eustatic cycles: Sedimentary Geology, v. 70, p. 131-160

Mitchum, R. M., Jr., Vail, P. R., and Thompson, S., III, 1977, Part II, The depositional sequence as a basic unit for stratigraphic analysis; in, Seismic stratigraphy applications to hydrocarbon exploration, Payton, C. E., ed.: American Association of Petroleum Geologists, Memoir 26, p. 53-62

Moore, R. C., 1931, Pennsylvanian cycles in the northern midcontinent region: Illinois Geological Survey, Bulletin 60, p. 247-257

Posamentier, H. W., James, D. P., and Allen, G. P., 1990, Aspects of sequence stratigraphy - recent and ancient examples of forced regressions (abs.): American Association of Petroleum Geologists Bulletin, v. 74, p. 742

Rascoe, B., Jr., and Adler, F. J., 1983, Permo-Carboniferous hydrocarbon accumulations, midcontinent U.S.A.: American Association of Petroleum Geologists Bulletin, v. 67, p. 979-1,001 


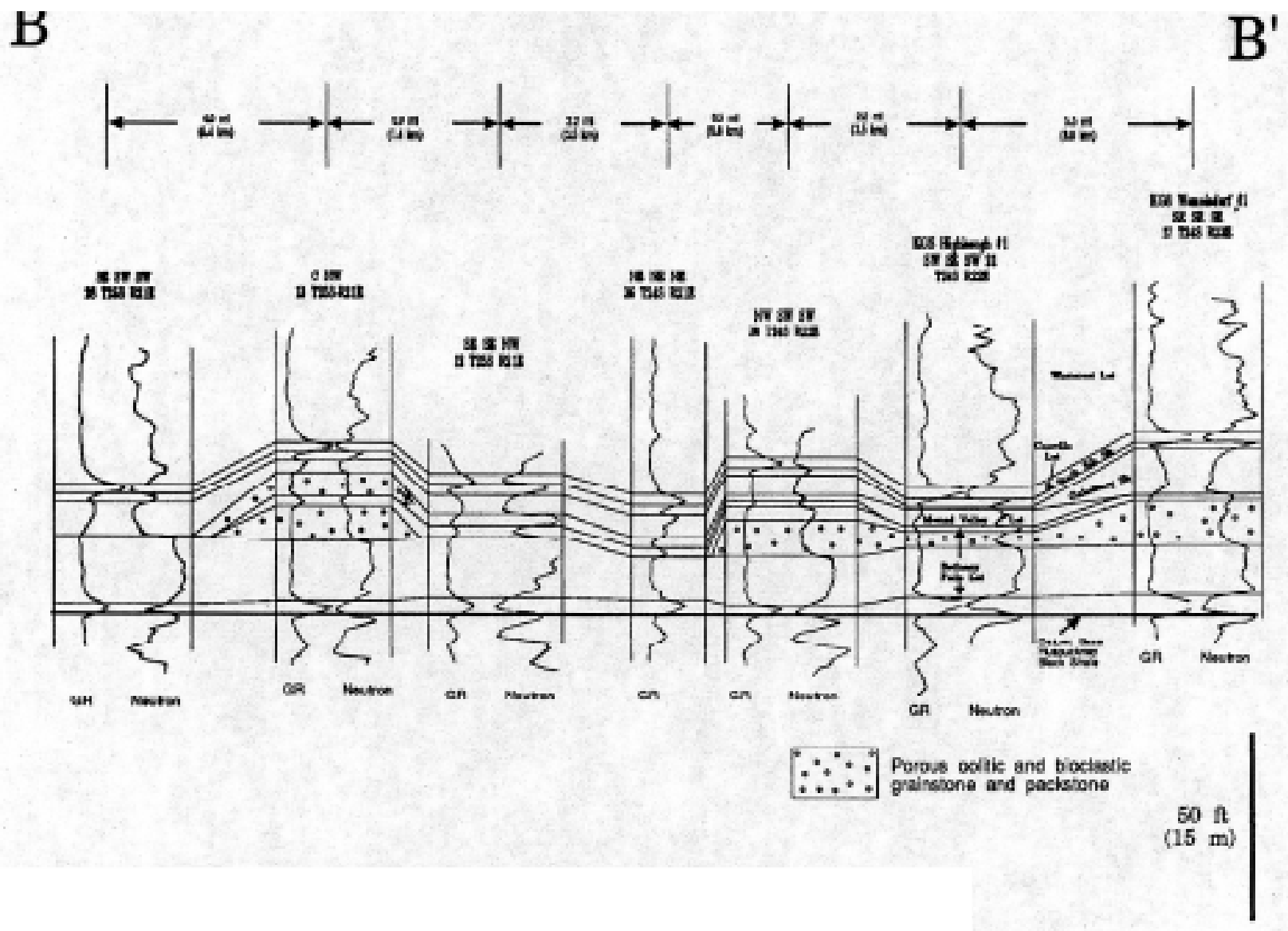

Figure 11. Detailed southwest-northeast-trending cross section (using the same wells as in fig. 10) showing the development of separate porosity zones both laterally and vertically in the Swope and Mound Valley limestones. Note the relatively abrupt lateral pinchouts of these oolitic lithofacies in both zones.

Udden, J. A., 1912, Geology and mineral resources of the Peoria Quadrangle, Illinois: U.S. Geological Survey, Professional Paper 506, $103 \mathrm{p}$.

Van Wagoner, J. C., Mitchum, R. M., Campion, K. M., and Rahmanian, V. D., 1990, Siliciclastic sequence stratigraphy in well logs, cores, and outcrops: AAPG Methods in Exploration Series 7, Tulsa, Oklahoma

Veevers, J. J., and Powell, C. M., 1987, Late Paleozoic glacial episodes in Gondwanaland reflected in transgressive-regressive depositional sequences in Euramerica: Geological Society of America Bulletin, v. 98, p. 475-487

Watney, W. L., 1980, Cyclic sedimentation of the Lansing and Kansas City Groups (Missourian) in northwestern Kansas and southwestern Nebraska-a guide for petroleum exploration: Kansas Geological Survey, Bulletin 220, 72 p.
Watney, W. L., 1984, Recognition of favorable reservoir trends in Upper Pennsylvanian cyclic carbonates in western Kansas; in, Limestones of the midcontinent, Hyne, N. J., ed.: Tulsa Geological Society, Special Publication 2, p. 201-246

Watney, W. L., and French, J. A., 1988, Characterization of carbonate reservoirs in the Lansing-Kansas City Groups (Upper Pennsylvanian) in Victory field, Haskell County, Kansas; in, Occurrence and petrophysical properties of carbonate reservoirs in the Rocky Mountain region, Goolsby, S. M., and Longman, M. W., eds.: 1988 Carbonate Symposium, Rocky Mountain Association of Geologists, p. 27-46

Watney, W. L., French, J. A., and Franseen, E. K., 1989, Sequencestratigraphic interpretations and modeling of cyclothems: Guidebook, 41st Annual Field Trip, Kansas Geological Survey and Kansas Geological Society, 211 . 


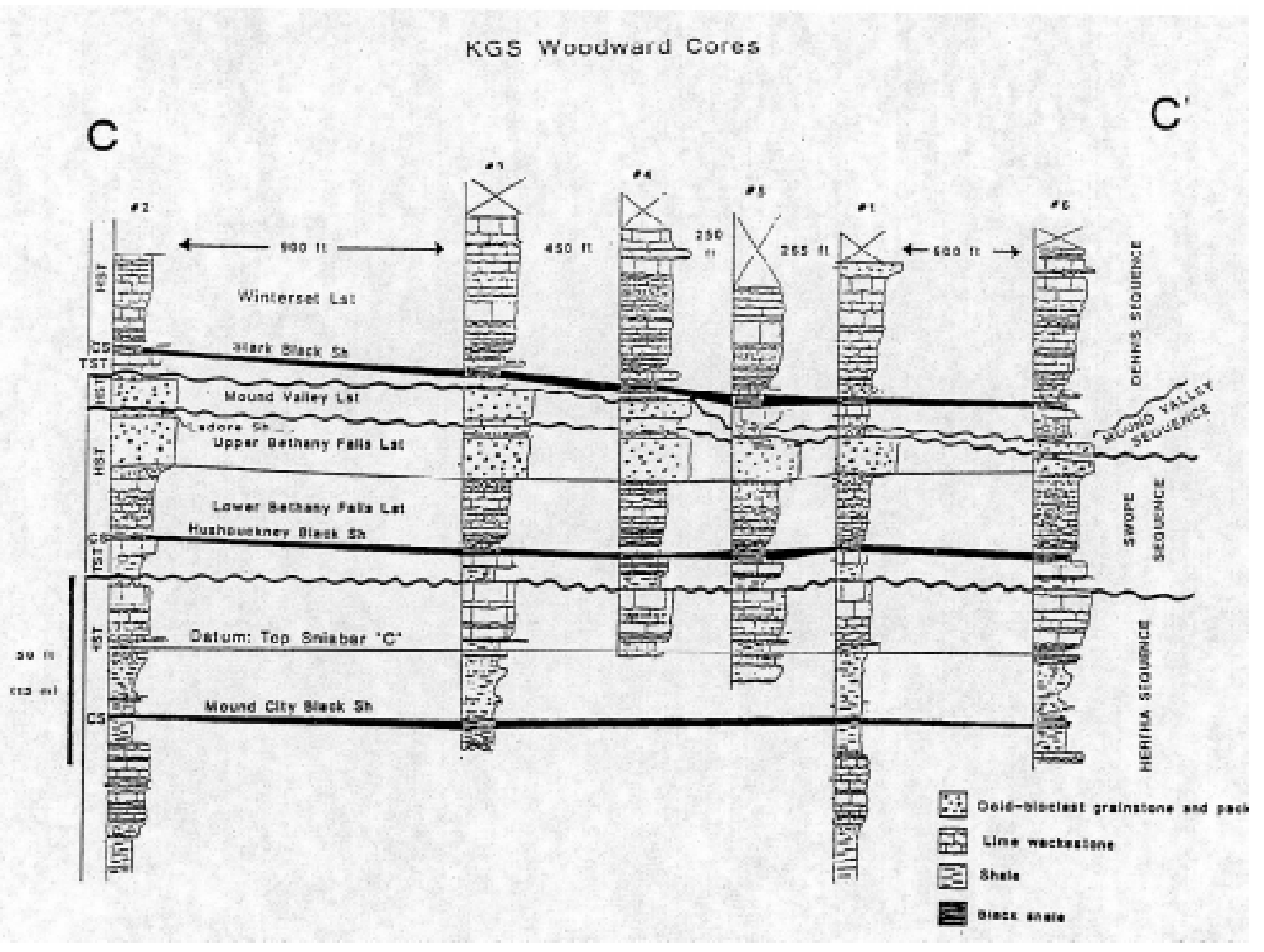

Figure 12. Detailed core transect from near the center toward the pinchout of an oolitic buildup in the Swope and Mound Valley depositional sequences. Porosity in these oolites varies both laterally and vertically, being controlled in part by the distribution of paleosols and relatively fine-grained transgressive lithofacies.

Watney, W. L., Stephens, B., and Wong, J. C., 1992, Cahoj fieldU.S.A., Anadarko basin, Kansas; in, Structural traps VI-treatise of petroleum geology atlas of oil and gas fields, Foster, N. H., and Beaumont, E. A., compilers: p. 239-273

Watney, W. L., French, J. A., Guy, B., Carlson, R., and Wong, J. C., 1993, Geological characterization of oolitic grainstone reservoirs in the Upper Pennsylvanian Lansing-Kansas City Groups in Victory Field and near-surface analogs in Kansas; in, Reservoir description workshop-application of underutilized technologies: Kansas Geological Survey, Open-File Report 93-5, p. 145-174

Weller, J. M., 1930, Cyclical sedimentation of the Pennsylvanian Period and its significance: Journal of Geology, v. 38, p. 97-135 